\section{BMJ Open Respiratory Research}

\title{
Presentation and healthcare delays among people with tuberculosis in London, and the impact on treatment outcome
}

\author{
Poppy Evenden (D , , ${ }^{1,2}$ Anita Roche, ${ }^{3}$ Basel Karo, ${ }^{2,4}$ Sooria Balasegaram, ${ }^{2}$ \\ Charlotte S Anderson ${ }^{2}$
}

To cite: Evenden $P$, Roche $A$, Karo B, et al. Presentation and healthcare delays among people with tuberculosis in London, and the impact on treatment outcome. BMJ Open Resp Res 2019;6:e000468. doi:10.1136/ bmjresp-2019-000468

Received 22 July 2019 Revised 3 September 2019 Accepted 4 September 2019

Check for updates

C Author(s) (or their employer(s)) 2019. Re-use permitted under CC BY-NC. No commercial re-use. See rights and permissions. Published by BMJ.

${ }^{1}$ ANTICPE, INSERM U1086, Caen, France

${ }^{2}$ Field Service, South East and London, Public Health England, London, UK

${ }^{3}$ South London Health Protection Team, Public Health England, London, UK ${ }^{4}$ ECDC, European Centre for Disease Prevention and Control, Solna, Sweden

Correspondence to Dr Charlotte S Anderson; charlotte.anderson@phe. gov.uk

\section{ABSTRACT}

Background A quarter of London's pulmonary tuberculosis (TB) patients have over 4 months of delay. Late diagnosis increases disease severity and the risk of transmission. We aim to classify delays, identify associated risk factors and assess treatment outcome.

Methods We conducted a retrospective cohort study using London surveillance data, 2012-2018 on adults aged $\geq 18$ years with pulmonary TB. We defined presentation delay (days from symptom onset to first healthcare visit) and healthcare delay (first healthcare visit to treatment commencement) as dichotomous variables; positive delay being days equal or greater than the third quartile. We applied logistic regression models to identify risk factors associated with delays and treatment outcome at 12 months.

Results 0 7216 people, 4539 reported presentation and 5193 healthcare delays. The third quartiles for presentation and healthcare delay were 84 and 61 days, respectively. Presentation delay was associated with female sex (adjusted OR $(\mathrm{aOR})=1.21 ; 95 \% \mathrm{Cl} 1.04$ to 1.39), increasing age (aOR=1.004; $95 \% \mathrm{Cl} 1.001$ to 1.008$)$, white compared to Asian ethnicity (aOR=1.35; $95 \% \mathrm{Cl} 1.12$ to 1.62), previous imprisonment (aOR=1.66; $95 \% \mathrm{Cl} 1.22$ to 2.26) and alcohol misuse (aOR=1.44; $95 \% \mathrm{Cl} 1.04$ to 1.89). Healthcare delay was associated with female sex (aOR=1.39; 95\% Cl 1.21 to 1.59), increasing age $(\mathrm{aOR}=1.014 ; 95 \% \mathrm{Cl} 1.009$ to 1.018$)$ and white ethnicity (aOR=1.41; $95 \% \mathrm{Cl} 1.19$ to 1.68). $16 \%$ of 5678 people with known outcome did not complete treatment. Neither delay was associated with non-completion ( $p$ value $<0.05$ ). Conclusions Female, white and older people with TB were more likely to experience both presentation and healthcare delays. Social risk factors were also associated with delay in presentation. Early diagnosis and treatment remain critical to reduce transmission, regardless of whether delay affected completion.

\section{BACKGROUND}

Tuberculosis (TB) is caused by the gram-positive aerobic bacteria of the Mycobacterium tuberculosis complex. TB is one of the top 10 causes of death worldwide. ${ }^{1}$ Although England is a low incidence country, TB is still a major public health concern in London, with a notification rate of 21.7 per 100000 and
Key messages

What is the key question?

- What are the risk factors associated with presentation and healthcare delay and is delay (presentation or healthcare delay) associated with treatment non-completion at 12 months?

What is the bottom line?

- Social risk factors such as imprisonment and alcohol misuse are the two most important risk factors for presentation delay, for healthcare delay female sex, increasing age and white ethnicity were associated and finally neither presentation delay nor healthcare delay were associated with treatment non-completion.

\section{Why read on?}

- Reducing delays in diagnosis is an opportunity to reduce transmission of tuberculosis (TB): by identifying characteristics and groups at risk of long delays, our findings will support local improvement strategies for TB programmes to try and reduce extreme delays further.

accounting for $37 \%$ of all cases in England in 2017. ${ }^{1-3}$ Studies in London have identified groups at increased risk of TB such as homeless people, prisoners, drug users, HIV positivity and people with comorbidities such as diabetes, asthma and immune-suppression. ${ }^{4-6}$

To reduce the TB burden, early diagnosis is crucial. Late diagnosis induces a more advanced and complex disease, higher rates of transmission and greater costs to the health service. ${ }^{7-9}$ Studies have shown delay in starting treatment to be an issue in both high and low TB incidence countries. ${ }^{10-19}$ Delay can be defined in various ways. Total delay is the time from symptom onset to treatment start. This can be subdivided into diagnostic delay (time from symptom onset to diagnosis) and treatment delay (from diagnosis to treatment start), or into presentation delay (time from symptom 
onset to first visit to a place of healthcare) and healthcare delay (from first visit to a place of healthcare to treatment start). In London, $27 \%$ of people with pulmonary TB had over 4 months of delay from symptom onset to treatment commencement, lower than the national proportion of $31 \% .^{2}$ The relative contribution of presentation delay or delay within the health service, and which groups are most at risk is unknown. ${ }^{3}$ Though there is no universally accepted period for total delay, the WHO recommend a delay of less than 3 weeks from symptom onset to seeking healthcare. $^{20}$

Total delay is associated with poorer treatment outcomes in high TB incidence countries. ${ }^{16} 17$ In London, treatment completion at 12 months for people notified with pulmonary drug sensitive TB in 2016 was $87 \%$, but the outcome among people who had delayed diagnosis has not been described. ${ }^{3}$ The aim of this study was to describe presentation and healthcare delay among people with TB in London, in order to identify associated risk factors and the effect on treatment outcome to help inform TB strategies in London.

\section{METHODS}

\section{Study design}

A retrospective cohort study was performed to identify factors associated with delay and treatment outcome of TB in London from 2012 to 2018. Presentation delay was defined as the time from symptom onset to the first visit to a place of healthcare. Healthcare delay was defined as the time from the first visit to a place of healthcare to the start of TB treatment. Due to the non-normal distribution of delay as a continuous variable, we dichotomised it into two groups, delayed and not delayed. The right skew observed in the distribution showed extreme lengths of delay, possibly due to mis-recording or forgetting exact dates, but this would still imply a significant delay while the exact length of delay at extremes had little clinical relevance. To avoid excluding people with extreme delays a dichotomous variable was preferred. We chose the third quartile as our binary cut-off point as it allowed us to focus on the risk factors associated with people who had the longest delays. Also, the third quartile corresponded to time intervals that were reasonable and achievable for health services to aim to reduce. A person would be considered as being delayed if their delay was equal or superior to the third quartile of the study population. For the secondary objective analysing the impact of delay on treatment outcome, outcome was defined as completed or not completed (all other remaining outcomes at 12 months from starting treatment).

\section{Study population}

People were selected from the Public Health England London TB register, a routine surveillance system used throughout London. Patient information is entered in the database by TB clinic staff. People diagnosed with pulmonary TB (with or without extrapulmonary sites), notified from 2012 to 2018 and 18 years of age or over at the start of treatment were included in this study. People with TB identified through contact tracing or TB screening programme were excluded. We analysed presentation delay and healthcare delay separately. All people with a negative or missing delay were excluded from the analysis of the respective delay.

To analyse treatment outcome, we excluded cases with central nervous system, miliary or spinal extrapulmonary TB sites, multidrug-resistant TB and rifampicin-resistant $\mathrm{TB}$ and people who started their treatment after the 31 December 2017.

To reduce the number of categories of ethnicity, Indian, Pakistani, Bangladeshi and Chinese were grouped into 'Asian/Asian-British' and black-African, black-Caribbean and black-other categories grouped into 'Black-African/ Black-Caribbean/Black-British' ${ }^{21}$

\section{Statistical analysis}

The study population was described by median and range for age (due to the non-normal distribution), median and IQR for delay and categorical variables were described by proportion (per cent).

Explanatory variables were selected, and missing data were quantified. In the subsets of data, there were less than $5 \%$ of missing data for each variable of interest therefore complete case analysis was performed.

We used logistic regression to analyse factors associated with presentation delay, healthcare delay and treatment outcome. After univariable analysis, all variables of interest associated with delay with a $p$ value $<0.25$ or clinically appropriate for the analysis were included in a first multivariable model. A backward selection was performed following the recommendations by Hosmer and Lemeshow to obtain the final model. ${ }^{22}$ Sensitivity analyses were performed by changing the point of positive delay, for

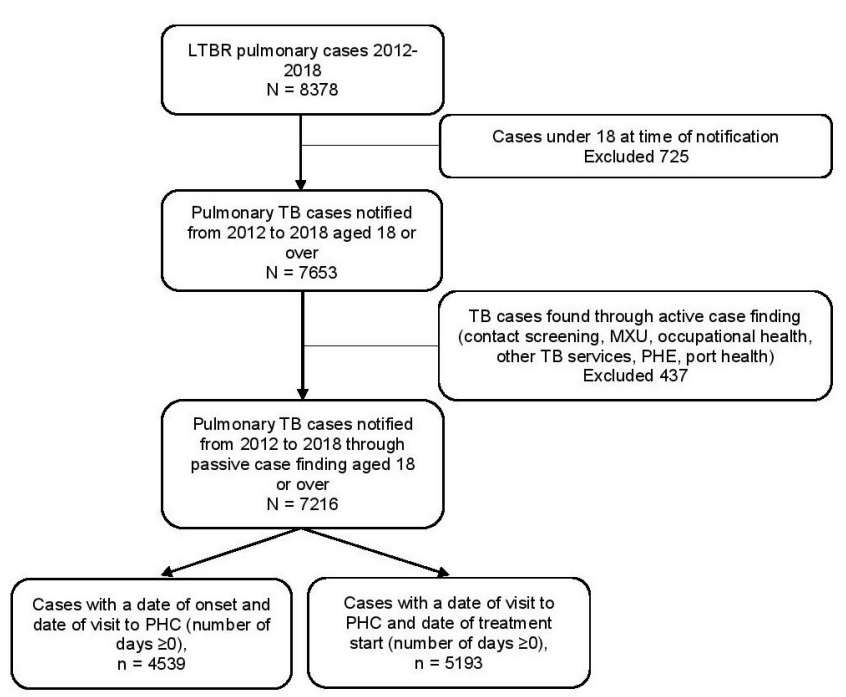

Figure 1 Flow chart of case selection for delay. LTBR, London TB register; MXU, mobile X-ray unit; PHC, place of healthcare; PHE, public health England; TB, tuberculosis. 


\begin{tabular}{llccc}
\hline Table 1 Summary of characteristics of the study populations & \multicolumn{1}{c}{$\begin{array}{l}\text { Total } \\
\text { cohort,n=7216 } \\
\text { (\%) }\end{array}$} & $\begin{array}{l}\text { Presentation } \\
\text { delay } \\
\text { cohort,n=4539 (\%) }\end{array}$ & $\begin{array}{l}\text { Healthcare delay } \\
\text { cohort,n=5193 }\end{array}$ & $\begin{array}{l}\text { Outcome } \\
\text { cohort, } \mathbf{n = 5 6 7 8} \\
\text { (\%) }\end{array}$ \\
\hline Variable & $4580(63)$ & $2918(64)$ & $3300(64)$ & $3588(63)$ \\
\hline Male & $38(18-105)$ & $38(18-105)$ & $39(18-105)$ & $37(18-105)$ \\
\hline Age, median (range) & $1487(21)$ & $942(21)$ & $1083(21)$ & $1221(22)$ \\
\hline UK born & & & & \\
\hline Ethnicity & $2624(36)$ & $1538(34)$ & $1751(34)$ & $2037(36)$ \\
\hline Asian/Asian-British & $1720(24)$ & $1139(25)$ & $1281(25)$ & $1335(24)$ \\
\hline Black-African/black-Caribbean/black-British & $1585(22)$ & $1022(23)$ & $1205(23)$ & $1277(22)$ \\
\hline White & $1253(17)$ & $827(18)$ & $938(18)$ & $1007(18)$ \\
\hline Other & $479(6.6)$ & $310(6.8)$ & $357(6.9)$ & $381(6.7)$ \\
\hline History of drug use & $458(6.3)$ & $310(6.8)$ & $353(6.8)$ & $354(6.2)$ \\
\hline History of homelessness & $332(4.6)$ & $215(4.7)$ & $253(4.9)$ & $265(4.7)$ \\
\hline History of imprisonment & $438(6.1)$ & $282(6.2)$ & $331(6.4)$ & $340(6.0)$ \\
\hline Alcohol misuse & $485(6.7)$ & $315(6.9)$ & $365(7.0)$ & $375(6.6)$ \\
\hline Mental health concerns & $5052(70)$ & $3274(72)$ & $3739(72)$ & $3984(70)$ \\
\hline Employed & & & & $1354(24)$ \\
\hline Place of healthcare & $1783(25)$ & $1576(35)$ & $1717(33)$ & $1982(35)$ \\
\hline Accident \& emergency (A\&E) & $2431(34)$ & $2054(45)$ & $2338(45)$ & $57(1.0)$ \\
\hline General practitioner & $71(1.0)$ & $56(1.2)$ & $68(1.3)$ & $891(16)$ \\
\hline Private sector & $1121(16)$ & $834(18)$ & $1048(20)$ & \\
\hline Other & & & & \\
\hline
\end{tabular}

presentation delay we used the 21-day WHO recommendation, and for both presentation and healthcare delay we used the median. Another sensitivity analysis was to change the missing data for social risk factors to the 'No' group. Statistical significance of the variables was set for two-sided $\mathrm{p}$ values $<0.05$.

All analysis and data cleaning were performed in $\mathrm{R}$ V.3.5.2.

\section{Patient and public involvement}

People included in this study were not involved in the analysis or the writing of this manuscript.

\section{RESULTS}

Of the 7216 people with pulmonary TB included in the study population, $37 \%$ were excluded from the presentation delay analysis and $28 \%$ were excluded from the healthcare delay analysis (figure 1).

The characteristics of our complete study population and in the two subsets for study of presentation and healthcare delay as well as the subset for treatment outcome, are shown in table 1.

\section{Presentation delay}

Of the 4539 people with a recorded presentation delay, the median age was 38 years, $64 \%$ were male and $21 \%$ born in the UK (table 1). The median presentation delay was 35 days (IQR 13-84). Using the third quartile (84 days) as the cut-off, 1149 cases were classed as delayed for presentation delay.

Univariable analysis (table 2) showed that social risk factors, such as a history of imprisonment $(\mathrm{OR}=1.90)$, a history of drug use $(\mathrm{OR}=1.58)$, alcohol misuse $(\mathrm{OR}=1.56)$, mental health concerns $(\mathrm{OR}=1.34)$ and history of homelessness $(\mathrm{OR}=1.30)$ were associated with being delayed 84 days or more. Other risk factors for delay included white ethnicity $(\mathrm{OR}=1.40)$ compared with Asian/Asian-British ethnicities, unemployment $(\mathrm{OR}=1.30)$ and increasing age $(\mathrm{OR}=1.004)$.

In the multivariable analysis, history of imprisonment (adjusted OR $(\mathrm{aOR})=1.66)$, alcohol misuse $(\mathrm{aOR}=1.44)$, white ethnicity $(\mathrm{aOR}=1.35)$ compared with Asian/AsianBritish ethnicities, female sex $(\mathrm{aOR}=1.21)$ and increasing age $(\mathrm{aOR}=1.004)$ were significantly associated with being delayed (table 3 ).

Sensitivity analyses (table 4) showed that if presentation delay was dichotomised at 21 days, which is the recommended limit for presentation delay by the WHO, only the social risk factors (history of imprisonment and alcohol misuse) remained associated with being delayed. Similarly, when using the median as a cut-off point, only imprisonment and alcohol misuse were associated with being delayed.

\section{Healthcare delay}

Of the 5193 people with reported healthcare delay, the median age was 39 years, $64 \%$ were male and $21 \%$ were 


\begin{tabular}{|c|c|c|c|c|c|}
\hline Variable & $\begin{array}{l}\text { Total, } \\
\text { n (\%) }\end{array}$ & $\begin{array}{l}\text { Delayed, } \\
\text { n (\% delayed) }\end{array}$ & OR & $95 \% \mathrm{Cl}$ & $P$ value \\
\hline \multicolumn{6}{|l|}{ Sex } \\
\hline Male & $2918(64)$ & $716(25)$ & Ref & & \\
\hline Female & $1621(36)$ & $433(27)$ & 1.12 & 0.98 to 1.29 & 0.11 \\
\hline Age, median (range) & $38(18-105)$ & $40(18-105)$ & 1.004 & 1.001 to 1.008 & 0.02 \\
\hline \multicolumn{6}{|l|}{ Born in the UK or time of residency } \\
\hline UK born & $942(21)$ & $274(29)$ & Ref & & \\
\hline Recent resident ( $<5$ years in the UK) & $1016(22)$ & $246(24)$ & 0.78 & 0.64 to 0.95 & 0.01 \\
\hline Longer resident ( $\geq 5$ years in the UK) & $2423(54)$ & $587(24)$ & 0.78 & 0.66 to 0.92 & 0.004 \\
\hline Years since arrival unknown & $145(3.2)$ & $41(28)$ & 0.96 & 0.65 to 1.41 & 0.84 \\
\hline \multicolumn{6}{|l|}{ Ethnicity } \\
\hline Asian/Asian-British & $1538(34)$ & $354(23)$ & Ref & & \\
\hline Black-African/black-Caribbean/black-British & $1139(25)$ & $293(26)$ & 1.16 & 0.97 to 1.38 & 0.11 \\
\hline White & $1022(23)$ & $301(29)$ & 1.40 & 1.17 to 1.67 & $<0.001$ \\
\hline Other & $827(18)$ & $199(24)$ & 1.06 & 0.87 to 1.29 & 0.57 \\
\hline \multicolumn{6}{|l|}{ Sputum smear result (at diagnosis) } \\
\hline Positive & $1971(44)$ & $507(26)$ & Ref & & \\
\hline Negative & $1799(40)$ & $452(25)$ & 0.97 & 0.84 to 1.12 & 0.67 \\
\hline Other (awaiting results, not done, unknown ...) & $768(17)$ & $190(25)$ & 0.95 & 0.78 to 1.15 & 0.58 \\
\hline \multicolumn{6}{|l|}{ Chest X-ray or CT (at diagnosis) } \\
\hline Cavities reported & $1368(30)$ & $359(26)$ & 1.09 & 0.94 to 1.26 & 0.26 \\
\hline Abnormalities reported & $3035(67)$ & $748(25)$ & Ref & & \\
\hline Other (awaiting results, not done, unknown ...) & $136(3.0)$ & $42(31)$ & 1.37 & 0.93 to 1.97 & 0.10 \\
\hline \multicolumn{6}{|l|}{ History of drug use } \\
\hline Yes & $310(7.0)$ & $106(34)$ & 1.58 & 1.23 to 2.01 & $<0.001$ \\
\hline No & $4139(93)$ & $1024(25)$ & Ref & & \\
\hline \multicolumn{6}{|l|}{ History of homelessness } \\
\hline Yes & $310(6.9)$ & $94(30)$ & 1.30 & 1.01 to 1.67 & 0.04 \\
\hline No & $4162(93)$ & $1041(25)$ & Ref & & \\
\hline \multicolumn{6}{|l|}{ History of imprisonment } \\
\hline Yes & $215(4.8)$ & $83(39)$ & 1.90 & 1.43 to 2.52 & $<0.001$ \\
\hline No & 4234 (95) & $1053(25)$ & Ref & & \\
\hline \multicolumn{6}{|l|}{ Alcohol misuse } \\
\hline Yes & $282(6.4)$ & $96(34)$ & 1.56 & 1.21 to 2.02 & $<0.001$ \\
\hline No & $4131(94)$ & $1025(25)$ & Ref & & \\
\hline \multicolumn{6}{|l|}{ Mental health concerns } \\
\hline Yes & $315(7.1)$ & $97(31)$ & 1.34 & 1.04 to 1.71 & 0.02 \\
\hline No & $4105(93)$ & $1025(25)$ & Ref & & \\
\hline \multicolumn{6}{|l|}{ Occupation } \\
\hline Employed* & $3274(76)$ & 807 (25) & Ref & & \\
\hline Unemployed $\dagger$ & 1019 (24) & $304(30)$ & 1.30 & 1.11 to 1.52 & $<0.001$ \\
\hline
\end{tabular}

Significant $p$ values $(<0.05)$ are highlighted in bold.

*Employed included all employment types, Plus housewives/husbands, students and retired people.

†Unemployed includes reported unemployed, prisoners, asylum seekers and immigration detainees.

Ref, reference group.

born in the UK (table 1). Using the third quartile of delay (61 days), 1320 cases were found to have a healthcare delay.
Univariable analysis showed that a negative sputum smear result at diagnosis $(\mathrm{OR}=2.51)$ was associated with being delayed, as was female sex $(\mathrm{OR}=1.43)$, white ethnicity 
Table 3 Final model for multivariable analysis for presentation delay

\begin{tabular}{llll}
\hline Variable & aOR & $\mathbf{9 5 \%} \mathbf{C l}$ & P value \\
\hline $\begin{array}{l}\text { Sex } \\
\text { Male }\end{array}$ & Ref & & \\
\hline Female & 1.21 & 1.04 to 1.39 & $\mathbf{0 . 0 1}$ \\
\hline Age & 1.004 & 1.000 to 1.008 & $\mathbf{0 . 0 3}$ \\
\hline $\begin{array}{l}\text { Ethnicity } \\
\text { Asian/Asian-British }\end{array}$ & Ref & & \\
\hline $\begin{array}{l}\text { Black-African/black- } \\
\text { Caribbean/black- }\end{array}$ & 1.15 & 0.95 to 1.38 & 0.14 \\
British & & & \\
\hline White & 1.35 & 1.12 to 1.62 & $\mathbf{0 . 0 0 2}$ \\
\hline $\begin{array}{l}\text { Other } \\
\text { History of imprisonment }\end{array}$ & 1.06 & 0.86 to 1.29 & 0.59 \\
\hline $\begin{array}{l}\text { Yes } \\
\text { No }\end{array}$ & 1.66 & 1.22 to 2.26 & $\mathbf{0 . 0 0 1}$ \\
\hline Alcohol misuse & Ref & & \\
\hline Yes & & & \\
\hline No & 1.44 & 1.08 to 1.89 & $\mathbf{0 . 0 1}$ \\
\hline
\end{tabular}

Significant $p$ values $(<0.05)$ are highlighted in bold.

aOR, adjusted OR; Ref, reference group.

( $\mathrm{OR}=1.34)$ compared with Asian/Asian-British ethnicities and increasing age $(\mathrm{OR}=1.015)$. However, being born abroad (resident less than 5 years: $\mathrm{OR}=0.70$, resident 5 years or more: $\mathrm{OR}=0.84$, time since arrival unknown: $\mathrm{OR}=0.64$ ) compared with UK born, having cavities reported from a chest X-ray $(\mathrm{OR}=0.61)$ compared with other abnormalities reported on the $\mathrm{X}$-ray, a history of drug use $(\mathrm{OR}=0.75)$, homelessness $(\mathrm{OR}=0.60)$ and alcohol misuse $(\mathrm{OR}=0.60)$, and attending any place of healthcare other than a general practitioner (accident and emergency service (A\&E): $\mathrm{OR}=0.22$, private sector: $\mathrm{OR}=0.51$, other place for healthcare: $\mathrm{OR}=0.68$ ) were significantly associated with not being delayed (table 5 ).

For the multivariable analysis, white ethnicity $(\mathrm{aOR}=1.41)$ compared with Asian/Asian-British ethnicities, female sex $(\mathrm{aOR}=1.39)$ and increasing age $(\mathrm{aOR}=1.014)$ remained associated with being delayed. Attending any place of healthcare than a general practitioner was associated with not being delayed over 60 days (A\&E: $\mathrm{aOR}=0.22$, private sector: $\mathrm{aOR}=0.48$ and any other place of healthcare: aOR=0.60) (table 6).

In sensitivity analysis using the median (21 days) for the cut-off, we found the same associations except for white ethnicity which was no longer associated with delay. Also, we found people with a history of homelessness and who were resident in the UK less than 5 years were less likely to be delayed 21 days or more (table 7).

\section{Treatment outcome}

We included 5678 (79\%) cases according to our criteria. The median age was 37 years, $63 \%$ were male and $78 \%$ were born abroad. A total of 4793 cases (84\%) had completed treatment at 12 months.

Univariable analysis (table 8) showed that neither a presentation delay of 84 days or more nor healthcare delay of 61 days or more was associated with non-completion of treatment at 12 months. Factors that were associated with not completing included alcohol misuse $(\mathrm{OR}=2.56)$, homelessness $(\mathrm{OR}=2.08)$, attending $\mathrm{A} \& \mathrm{E}$ $(\mathrm{OR}=2.00)$ compared with a general practitioner, drug use $(\mathrm{OR}=1.90)$, mental health concerns $(\mathrm{OR}=1.69)$, unemployment $(\mathrm{OR}=1.48)$ and increasing age $(\mathrm{OR}=1.016)$. Female sex $(\mathrm{OR}=0.73)$, black-African/black-Caribbean/ black-British ethnicities $(\mathrm{OR}=0.75)$ compared with Asian/Asian-British ethnicities and a negative sputum smear result at diagnosis $(\mathrm{OR}=0.76)$ compared with a positive result were variables associated with treatment completion at 12 months.

In multivariable analysis (table 9), presentation delay $(\mathrm{aOR}=0.98)$ and healthcare delay $(\mathrm{aOR}=1.00)$ were not associated with treatment non-completion at 12 months. Alcohol misuse $(\mathrm{aOR}=1.97)$, history of drug use $(\mathrm{aOR}=1.71)$, attending $\mathrm{A} \& \mathrm{E}(\mathrm{aOR}=1.66)$ compared with a general practitioner, resident $<5$ years in the UK $(\mathrm{aOR}=1.44)$ compared with UK born and increasing age $(\mathrm{aOR}=1.018)$ were all associated with not completing. People of black-African/black-Caribbean/black-British $(\mathrm{aOR}=0.72)$ and white ethnicity $(\mathrm{aOR}=0.64)$ compared

Table 4 Significant variables in sensitivity analyses for presentation delay

\begin{tabular}{|c|c|c|c|c|c|c|}
\hline \multirow[b]{2}{*}{ Variable } & \multicolumn{2}{|c|}{$\begin{array}{l}\text { Cut-off=21 days (WHO } \\
\text { recommendation) }\end{array}$} & \multicolumn{2}{|c|}{ Cut-off=35 days (median) } & \multicolumn{2}{|c|}{ Cut-off $=84$ days (third quartile) } \\
\hline & aOR & $95 \% \mathrm{Cl}$ & aOR & $95 \% \mathrm{Cl}$ & aOR & $95 \% \mathrm{Cl}$ \\
\hline Female sex & * & * & * & * & 1.21 & 1.04 to 1.39 \\
\hline Age & * & * & * & * & 1.004 & 1.00 to 1.008 \\
\hline White ethnicity & * & * & * & * & 1.35 & 1.12 to 1.62 \\
\hline History of imprisonment & 1.30 & 0.92 to 1.86 & 1.48 & 1.08 to 2.04 & 1.66 & 1.22 to 2.26 \\
\hline Alcohol misuse & 1.43 & 1.04 to 1.98 & 1.32 & 0.99 to 1.75 & 1.44 & 1.08 to 1.89 \\
\hline
\end{tabular}

In bold the significant results in analyses.

*Variables not selected in final model.

aOR, adjusted OR. 


\begin{tabular}{|c|c|c|c|c|c|}
\hline Variable & $\begin{array}{l}\text { Total, } \\
\text { n (\%) }\end{array}$ & $\begin{array}{l}\text { Delayed, } \\
\text { n (\% delayed) }\end{array}$ & OR & $95 \% \mathrm{Cl}$ & $P$ value \\
\hline \multicolumn{6}{|l|}{ Sex } \\
\hline Male & $3300(64)$ & $755(23)$ & Ref & & \\
\hline Female & $1893(36)$ & $565(30)$ & 1.43 & 1.26 to 1.63 & $<0.001$ \\
\hline Age, median (range) & $39(18-105)$ & $43(18-95)$ & 1.015 & 1.011 to 1.018 & $<0.001$ \\
\hline UK born & $1083(21)$ & $314(29)$ & Ref & & \\
\hline Recent resident ( $<5$ years in the UK) & $1143(22)$ & $253(22)$ & 0.70 & 0.57 to 0.84 & $<0.001$ \\
\hline Longer resident ( $\geq 5$ years in the UK) & $2765(53)$ & $707(26)$ & 0.84 & 0.72 to 0.98 & 0.03 \\
\hline Years since arrival unknown & $188(3.6)$ & $39(21)$ & 0.64 & 0.44 to 0.92 & 0.02 \\
\hline \multicolumn{6}{|l|}{ Ethnicity } \\
\hline Other & $827(18)$ & $242(29)$ & 1.06 & 0.88 to 1.27 & 0.52 \\
\hline \multicolumn{6}{|l|}{ Sputum smear result (at diagnosis) } \\
\hline Positive & $2151(42)$ & $321(15)$ & Ref & & \\
\hline Negative & $2151(42)$ & $657(31)$ & 2.51 & 2.16 to 2.92 & $<0.001$ \\
\hline Other (awaiting results, not done. Unknown ...) & $891(17)$ & $342(38)$ & 3.55 & 2.97 to 4.25 & $<0.001$ \\
\hline \multicolumn{6}{|l|}{ Chest X-ray or CT (at diagnosis) } \\
\hline Cavities reported & $1530(30)$ & $292(19)$ & 0.61 & 0.53 to 0.71 & $<0.001$ \\
\hline Abnormalities reported & $3506(68)$ & $972(28)$ & Ref & & \\
\hline Other (awaiting results, not done, unknown ...) & $157(3.0)$ & $56(36)$ & 1.45 & 1.03 to 2.01 & 0.03 \\
\hline \multicolumn{6}{|l|}{ History of imprisonment } \\
\hline Yes & $253(5.0)$ & $57(23)$ & 0.84 & 0.62 to 1.13 & 0.26 \\
\hline No & $4847(95)$ & $1245(26)$ & Ref & & \\
\hline \multicolumn{6}{|l|}{ Alcohol misuse } \\
\hline Yes & $331(6.6)$ & $58(18)$ & 0.60 & 0.44 to 0.80 & $<0.001$ \\
\hline No & $4720(93)$ & $1234(26)$ & Ref & & \\
\hline \multicolumn{6}{|l|}{ Mental health concerns } \\
\hline Yes & $365(7.2)$ & $97(27)$ & 1.06 & 0.83 to 1.34 & 0.64 \\
\hline No & $4695(93)$ & $1196(25)$ & Ref & & \\
\hline \multicolumn{6}{|l|}{ Place of healthcare } \\
\hline A\&E & $1717(33)$ & $184(11)$ & 0.22 & 0.18 to 0.26 & $<0.001$ \\
\hline General practitioner & $2338(45)$ & $832(36)$ & Ref & & \\
\hline Private sector & $68(1.3)$ & $15(22)$ & 0.51 & 0.28 to 0.89 & 0.02 \\
\hline Other (inpatient, outpatient, laboratory, prison) & $1048(20)$ & $285(27)$ & 0.68 & 0.58 to 0.79 & $<0.001$ \\
\hline Unknown & $22(0.42)$ & $4(18)$ & 0.40 & 0.12 to 1.08 & 0.10 \\
\hline \multicolumn{6}{|l|}{ Occupation } \\
\hline Employed $^{*}$ & $3739(76)$ & $1011(27)$ & Ref & & \\
\hline Unemployed $†$ & $1150(24)$ & $266(23)$ & 0.81 & 0.69 to 0.95 & 0.008 \\
\hline
\end{tabular}

Significant $p$ values $(<0.05)$ are highlighted in bold.

*Employed included all employment types, plus housewives/husbands, students and retired people.

tUnemployed includes reported unemployed, prisoners, asylum seekers and immigration detainees.

A\&E, accident and emergency; Ref, reference group. 
Table 6 Final model for multivariable analysis for healthcare delay

\begin{tabular}{|c|c|c|c|}
\hline Variable & aOR & $95 \% \mathrm{Cl}$ & $P$ value \\
\hline \multicolumn{4}{|l|}{ Sex } \\
\hline Male & Ref & & \\
\hline Female & 1.39 & 1.21 to 1.59 & $<0.001$ \\
\hline Age & 1.014 & 1.009 to 1.018 & $<0.001$ \\
\hline \multicolumn{4}{|l|}{ Ethnicity } \\
\hline Asian/Asian-British & Ref & & \\
\hline $\begin{array}{l}\text { Black-African/black- } \\
\text { Caribbean/black- } \\
\text { British }\end{array}$ & 0.97 & 0.81 to 1.16 & 0.75 \\
\hline White & 1.41 & 1.19 to 1.68 & $<0.001$ \\
\hline Other & 1.22 & 1.00 to 1.47 & 0.05 \\
\hline \multicolumn{4}{|l|}{ Place of healthcare } \\
\hline A\&E & 0.22 & 0.18 to 0.26 & $<0.001$ \\
\hline General practitioner & Ref & & \\
\hline Private sector & 0.48 & 0.26 to 0.85 & 0.01 \\
\hline $\begin{array}{l}\text { Other (inpatient, } \\
\text { outpatient, laboratory, } \\
\text { prison) }\end{array}$ & 0.60 & 0.51 to 0.71 & $<0.001$ \\
\hline Unknown & 0.40 & 0.11 to 1.09 & 0.10 \\
\hline
\end{tabular}

Significant $p$ values $(<0.05)$ are highlighted in bold.

A\&E, accident and emergency; aOR, adjusted OR; Ref, reference group.

with Asian/Asian-British ethnicities were more likely to complete treatment. Though when both delays were taken out of the model, unemployment was associated with non-completion, whereas females were significantly associated with treatment completion.

When changing the cut-off point of healthcare delay to the median (21 days) for the sensitivity analyses, people who were delayed were less likely to complete treatment $(\mathrm{aOR}=1.32,95 \%$ CI 1.09 to 1.59$)$. There remained no association between presentation delay and outcome even after changing the threshold (21 or 35 days) (data not shown).

\section{DISCUSSION}

In our study, people with pulmonary TB took longer from first onset of symptoms to first presenting at healthcare, than the delay between presenting and starting treatment for TB. This was similar to previous studies in London, ${ }^{2324}$ and around the world. ${ }^{1012131925}$ However, in some places healthcare delay was longer than presentation delay, notably studies in the south east of England, ${ }^{18}$ France ${ }^{15}$ and Norway. ${ }^{26}$ This may be due to differences in service provision and low clinical suspicion for TB since these areas have low TB incidence.

The increased risk of both presentation and healthcare delay experienced by females is a common finding around the world and in the UK. ${ }^{814182327-29}$ In our study, this association was no longer found if we lowered the threshold for presentation delay. Reasons for this finding are not clear. Nevertheless, the association with healthcare delay persisted, suggesting an inherent bias in suspicion of TB or even other health issues by health providers. White ethnicity as compared with Asian ethnicity has also been associated with longer overall delay in other studies in the UK. ${ }^{27}{ }^{28}$ White ethnicity in our study could be associated with vulnerable and marginalised groups which are likely to have a delay in presentation. The longer healthcare delay for people of white ethnicity could be explained by a heightened clinical suspicion and investigation in Asian ethnicities. The association of increasing age with overall delay was found in many studies. ${ }^{17} 182428$ While underlying medical conditions or more common alternative diagnoses could result in a healthcare delay among older people, it is not clear why they should present later.

Concerning presentation delay alone, previous imprisonment and alcohol misuse were associated with presentation delay. These indicate the individual may have a chaotic lifestyle leading to a lack of attention to their health, as well as poor past experience with health professionals resulting in delaying visits to healthcare. Multiple studies have found alcohol misuse to be associated with longer total delay. ${ }^{8}$

Table 7 Significant variables in sensitivity analysis for healthcare delay

\begin{tabular}{|c|c|c|c|c|}
\hline \multirow[b]{2}{*}{ Variable } & \multicolumn{2}{|c|}{ Cut-off=21 days (median) } & \multicolumn{2}{|c|}{ Cut-off $=61$ days (third quartile) } \\
\hline & aOR & $95 \% \mathrm{Cl}$ & aOR & $95 \% \mathrm{Cl}$ \\
\hline Female sex & 1.29 & 1.14 to 1.47 & 1.39 & 1.21 to 1.59 \\
\hline Age & 1.013 & 1.009 to 1.017 & 1.014 & 1.009 to 1.018 \\
\hline White ethnicity & 1.13 & 0.94 to 1.34 & 1.41 & 1.19 to 1.68 \\
\hline Less than 5 years in the UK & 0.77 & 0.64 to 0.94 & * & * \\
\hline History of homelessness & 0.69 & 0.53 to 0.89 & * & * \\
\hline$A \& E$ & 0.19 & 0.17 to 0.22 & 0.22 & 0.18 to 0.26 \\
\hline Private sector & 0.35 & 0.21 to 0.57 & 0.48 & 0.26 to 0.85 \\
\hline Other PHC & 0.48 & 0.41 to 0.56 & 0.60 & 0.51 to 0.71 \\
\hline
\end{tabular}

In bold the significant results in analyses.

*Variables not selected in final model.

$\mathrm{A} \& \mathrm{E}$, accident and emergency; $\mathrm{PHC}$, place of healthcare. 
Table 8 Description and ORs for univariable analysis for non-completion of treatment at 12 months, complete case analysis per individual variable

\begin{tabular}{|c|c|c|c|c|c|}
\hline Variable & $\begin{array}{l}\text { Total, } \\
\text { n (\% of population) }\end{array}$ & $\begin{array}{l}\text { Not completed, } \\
\text { n (\% not } \\
\text { completed) }\end{array}$ & OR & $95 \% \mathrm{Cl}$ & $P$ value \\
\hline \multicolumn{6}{|l|}{ Sex } \\
\hline Male & $3588(63)$ & $612(17)$ & Ref & & \\
\hline Female & $2090(37)$ & $273(13)$ & 0.73 & 0.63 to 0.85 & $<0.001$ \\
\hline Age, median (range) & $37(18-105)$ & $43(18-95)$ & 1.016 & 1.011 to 1.021 & $<0.001$ \\
\hline \multicolumn{6}{|l|}{ Born in the UK or resident } \\
\hline Born in the UK & $1221(22)$ & $192(16)$ & Ref & & \\
\hline Recent resident ( $<5$ years in the UK) & $1347(24)$ & $240(18)$ & 1.16 & 0.94 to 1.43 & 0.16 \\
\hline Longer resident ( $\geq 5$ years in the UK) & $2784(49)$ & $385(14)$ & 0.86 & 0.71 to 1.04 & 0.11 \\
\hline Time since entry unknown & $303(5.4)$ & $64(21)$ & 1.44 & 1.04 to 1.96 & 0.03 \\
\hline \multicolumn{6}{|l|}{ Ethnicity } \\
\hline Asian/Asian-British & $2037(36)$ & $323(16)$ & Ref & & \\
\hline Black-African/black-Caribbean/black-British & $1335(24)$ & $166(12)$ & 0.75 & 0.62 to 0.92 & 0.006 \\
\hline White & $1277(23)$ & $226(18)$ & 1.14 & 0.95 to 1.37 & 0.17 \\
\hline Other & $1007(18)$ & $164(16)$ & 1.03 & 0.84 to 1.27 & 0.76 \\
\hline \multicolumn{6}{|l|}{ Sputum smear result (at diagnosis) } \\
\hline Positive & $1895(33)$ & $347(18)$ & Ref & & \\
\hline Negative & $1818(32)$ & $266(15)$ & 0.76 & 0.64 to 0.91 & 0.003 \\
\hline Other (awaiting results, not done, unknown ...) & 1965 (35) & $272(14)$ & 0.72 & 0.60 to 0.85 & $<0.001$ \\
\hline \multicolumn{6}{|l|}{ Chest X-ray or CT (at diagnosis) } \\
\hline Cavities reported & $1337(24)$ & $228(17)$ & 1.07 & 0.90 to 1.27 & 0.46 \\
\hline Abnormalities reported & $2915(51)$ & $471(16)$ & Ref & & \\
\hline Other (awaiting results, not done, unknown ...) & $1426(25)$ & $186(13)$ & 0.78 & 0.65 to 0.93 & 0.007 \\
\hline \multicolumn{6}{|l|}{ History of drug use } \\
\hline Yes & $381(6.9)$ & $93(24)$ & 1.90 & 1.48 to 2.43 & $<0.001$ \\
\hline No & $5184(93)$ & $752(15)$ & Ref & & \\
\hline \multicolumn{6}{|l|}{ History of homelessness } \\
\hline Yes & $354(6.3)$ & $93(26)$ & 2.08 & 1.62 to 2.66 & $<0.001$ \\
\hline No & $5245(94)$ & $767(15)$ & Ref & & \\
\hline \multicolumn{6}{|l|}{ History of imprisonment } \\
\hline Yes & $265(4.8)$ & $64(24)$ & 1.85 & 1.37 to 2.46 & $<0.001$ \\
\hline No & $5314(95)$ & $782(15)$ & Ref & & \\
\hline \multicolumn{6}{|l|}{ Alcohol misuse } \\
\hline Yes & $340(6.3)$ & $101(30)$ & 2.56 & 1.99 to 3.26 & $<0.001$ \\
\hline No & $5104(94)$ & $724(14)$ & Ref & & \\
\hline \multicolumn{6}{|l|}{ Mental health concerns } \\
\hline Yes & $375(6.8)$ & $84(22)$ & 1.69 & 1.30 to 2.17 & $<0.001$ \\
\hline No & $5139(93)$ & $751(15)$ & Ref & & \\
\hline \multicolumn{6}{|l|}{ First healthcare practitioner to visit } \\
\hline$A \& E$ & $1354(24)$ & $286(21)$ & 2.00 & 1.66 to 2.42 & $<0.001$ \\
\hline General practitioner & $1982(35)$ & $234(12)$ & Ref & & \\
\hline Private sector & $57(1.00)$ & $4(7.0)$ & 0.56 & 0.17 to 1.39 & 0.27 \\
\hline Other (inpatient, outpatient, laboratory, prison) & $891(16)$ & $172(19)$ & 1.79 & 1.44 to 2.21 & $<0.001$ \\
\hline Unknown & $1394(25)$ & $189(14)$ & 1.17 & 0.95 to 1.44 & 0.13 \\
\hline \multicolumn{6}{|l|}{ Occupation } \\
\hline Employed* $^{*}$ & $3984(76)$ & $559(14)$ & Ref & & \\
\hline Unemployed $\dagger$ & $1248(24)$ & $243(19)$ & 1.48 & 1.25 to 1.75 & $<0.001$ \\
\hline
\end{tabular}


Table 8 Continued

\begin{tabular}{|c|c|c|c|c|c|}
\hline Variable & $\begin{array}{l}\text { Total, } \\
\text { n (\% of population) }\end{array}$ & $\begin{array}{l}\text { Not completed, } \\
\text { n (\% not } \\
\text { completed) }\end{array}$ & OR & $95 \% \mathrm{Cl}$ & $P$ value \\
\hline \multicolumn{6}{|l|}{ Presentation delay } \\
\hline Not delayed (<84 days) & $2653(74)$ & $426(16)$ & Ref & & \\
\hline Delayed ( $\geq 84$ days) & $933(26)$ & $145(16)$ & 0.97 & 0.78 to 1.19 & 0.76 \\
\hline \multicolumn{6}{|l|}{ Healthcare delay } \\
\hline Not delayed ( $<61$ days) & $3105(75)$ & $525(17)$ & Ref & & \\
\hline Delayed ( $\geq 61$ days) & $1060(25)$ & $152(14)$ & 0.82 & 0.67 to 1.00 & 0.05 \\
\hline
\end{tabular}

Significant $p$ values $(<0.05)$ are highlighted in bold.

*Employed included all employment types, plus housewives/husbands, students and retired people.

†Unemployed includes reported unemployed, prisoners, asylum seekers and immigration detainees.

A\&E, accident and emergency; Ref, reference group.

Concerning healthcare delay alone, people who attended a general practitioner were more likely to be delayed than those attending A\&E or other services which is consistent with many studies. ${ }^{10-14} 2425$ General practitioners are in a primary healthcare setting and have to refer to specialised services for TB diagnosis and treatment, which will incur some delay. However, additional delays in referral may occur due to low suspicion of TB. People who attend A\&E may have more severe symptoms or have difficulty accessing primary care services due to misunderstanding the healthcare service or immigration status. This would induce a shorter healthcare delay due to faster investigation, and easier access to diagnostic tools and specialists within a hospital setting.

In our cohort, $84 \%$ of people completed treatment, higher than other European countries, ${ }^{30} 31$ yet below the WHO target of $90 \% .{ }^{1}$ We found no evidence that delay was associated with not completing treatment. Delay is known to negatively affect treatment outcome in high-TB-incidence countries like Ethiopia or China in terms of death, loss to follow-up and treatment failure but we did not identify any studies from low-TB incidence countries. ${ }^{17}{ }^{32}$ No association was found between either delay and not completing treatment when using the third quartile for dichotomisation though an association was found with healthcare delay when using the median. This finding could be attributed to chance or that a longer presentation or healthcare delay relate to less severe symptoms or disease, since we are controlling for other social risk factors and sociodemographic variables. Conversely, some patients at risk of poor treatment outcome due to symptom severity may be fast-tracked through the health service. Therefore, it is more difficult to judge the relationship of healthcare delay to treatment outcome. Moreover, our outcome simply characterises treatment completion at 12 months, and cannot cover more subtle consequences of delay such as worsening patient health or necessity for extended treatment.

\section{Strengths and limitations}

This study is subject to recall bias due to the dates of symptom onset and visit to a place of healthcare being reported retrospectively by the people included in the study only after diagnosis. This bias could be differential if recall differed between subgroups. We chose to make delay a binary variable, meaning we lost information from the continuous variable, however, the extreme right skew of delay would have otherwise implied associations with long delay that may not have been directly related to the length of delay. The choice of dichotomisation also allowed us to focus on the most delayed group. When we reduced the cut-off for delay, this made the outcome variable broader, in this situation we found similar results, but finer associations were not captured. Data for presentation delay and healthcare delay were missing in $37 \%$ and $28 \%$ of cases, respectively. We believe that the subsets of the population were representative of the whole study population but due to complete case analysis, our findings may be under or over-estimated. Also, when considering the missing values for social risk factors as 'no', our results were the same as those found in our initial analysis. When analysing outcome, we included isoniazid-resistant TB as their treatment should be completed within 12 months. We used treatment completion which is a broad outcome since this does not assess the actual health outcomes of people after they have completed their treatment regimen. Finally, extrapolation of these results must be done with caution, as the London population of people with TB is likely to differ from other parts of the UK or abroad, as will access to local healthcare services.

\section{Recommendations}

Though there is no recommendation on an acceptable length of delay, overall delay in London was shorter than for England as a whole. ${ }^{2}$ In London, presentation delay was longer than healthcare delay, so a focus on reducing this will lead to more overall reduction in delays. In London, increasing TB knowledge among people who work with vulnerable groups could help ensure that these groups are registered with a general practitioner and early healthcare assessment could be arranged for those who have symptoms. TB awareness in healthcare practitioners must be maintained, especially in the context of 
Table 9 Final model for multivariable analysis for treatment non-completion at 12 months

\begin{tabular}{|c|c|c|c|}
\hline Variable & aOR & $95 \% \mathrm{Cl}$ & $P$ value \\
\hline \multicolumn{4}{|l|}{ Sex } \\
\hline Male & Ref & & \\
\hline Female & 0.82 & 0.66 to 1.01 & 0.07 \\
\hline Age & 1.018 & 1.012 to 1.024 & $<0.001$ \\
\hline \multicolumn{4}{|l|}{ Born in the UK or resident } \\
\hline Born in the UK & Ref & & \\
\hline $\begin{array}{l}\text { Recent resident ( }<5 \text { years } \\
\text { in the UK) }\end{array}$ & 1.44 & 1.05 to 1.98 & 0.02 \\
\hline $\begin{array}{l}\text { Longer resident ( } \geq 5 \text { years } \\
\text { in the UK) }\end{array}$ & 0.78 & 0.58 to 1.03 & 0.08 \\
\hline Time since entry unknown & 1.22 & 0.65 to 2.18 & 0.51 \\
\hline \multicolumn{4}{|l|}{ Ethnicity } \\
\hline Asian/Asian-British & Ref & & \\
\hline $\begin{array}{l}\text { Black-African/black- } \\
\text { Caribbean/black-British }\end{array}$ & 0.72 & 0.54 to 0.95 & 0.02 \\
\hline White & 0.64 & 0.48 to 0.86 & 0.003 \\
\hline Other & 1.01 & 0.77 to 1.32 & 0.95 \\
\hline \multicolumn{4}{|l|}{ History of drug use } \\
\hline Yes & 1.71 & 1.17 to 2.46 & 0.005 \\
\hline No & Ref & & \\
\hline \multicolumn{4}{|l|}{ Alcohol misuse } \\
\hline Yes & 1.97 & 1.36 to 2.81 & $<0.001$ \\
\hline No & Ref & & \\
\hline \multicolumn{4}{|l|}{$\begin{array}{l}\text { First healthcare practitioner } \\
\text { to visit }\end{array}$} \\
\hline$A \& E$ & 1.66 & 1.32 to 2.09 & $<0.001$ \\
\hline General practitioner & Ref & & \\
\hline Private sector & 0.60 & 0.14 to 1.71 & 0.41 \\
\hline $\begin{array}{l}\text { Other (inpatient, outpatient, } \\
\text { laboratory, prison) }\end{array}$ & 1.37 & 1.03 to 1.80 & 0.03 \\
\hline Unknown & 1.25 & 0.19 to 4.87 & 0.77 \\
\hline \multicolumn{4}{|l|}{ Occupation } \\
\hline Employed $^{*}$ & Ref & & \\
\hline Unemployed $†$ & 1.16 & 0.91 to 1.47 & 0.22 \\
\hline \multicolumn{4}{|l|}{ Presentation delay } \\
\hline Not delayed (<84 days) & Ref & & \\
\hline Delayed ( $\geq 84$ days) & 0.98 & 0.78 to 1.22 & 0.86 \\
\hline \multicolumn{4}{|l|}{ Healthcare delay } \\
\hline Not delayed (<61 days) & Ref & & \\
\hline Delayed ( $\geq 61$ days) & 1.00 & 0.77 to 1.28 & 0.98 \\
\hline
\end{tabular}

Significant $p$ values $(<0.05)$ are highlighted in bold.

*Employed included all employment types, plus housewives/husbands,

students and retired people.

†Unemployed includes reported unemployed, prisoners, asylum seekers and immigration detainees.

A\&E, accident and emergency; aOR, adjusted OR; Ref, reference group.

reducing TB rates. Our study found that social risk factors are associated with delays, supporting the UK guidance on heightened awareness and where appropriate active case finding in these groups. ${ }^{33}$

Unnecessary delays along the patient pathway should be assessed locally to identify any systematic issues that can be addressed. Cohort review provides an opportunity to improve quality of data collection on delays and identify local issues for action.

Additional studies are needed to better understand why females in particular are at increased risk of delays.

Acknowledgements We wish to acknowledge the contribution of all nurses and clinicians from all tuberculosis clinics in London for the data they collect without which these studies would not be possible. Also, we wish to thank Jacqui Carless and Neil Billingham for data extraction from the LTBR. All authors have contributed to the writing of this paper.

Contributors PE, SB and CSA designed the study. PE performed all statistical analysis with advice from SB and CSA. AR and BK provided input from their respective fields to the paper written by PE under guidance from SB and CSA. All authors approved the final manuscript.

Funding The authors have not declared a specific grant for this research from any funding agency in the public, commercial or not-for-profit sectors.

Competing interests None declared.

Patient consent for publication Not required.

Provenance and peer review Not commissioned; externally peer reviewed Data availability statement Data are available upon reasonable request.

Open access This is an open access article distributed in accordance with the Creative Commons Attribution Non Commercial (CC BY-NC 4.0) license, which permits others to distribute, remix, adapt, build upon this work non-commercially, and license their derivative works on different terms, provided the original work is properly cited, appropriate credit is given, any changes made indicated, and the use is non-commercial. See: http://creativecommons.org/licenses/by-nc/4.0/.

ORCID iD

Poppy Evenden http://orcid.org/0000-0002-5644-9734

\section{REFERENCES}

1 WHO. Global tuberculosis report 2018. Licence: CC BY-NC-SA 3.0 IGO. Geneva World Health Organization; 2018.

2 Public Health England. Tuberculosis in England: 2018. London Public Health England; 2018.

3 Public Health England. Tuberculosis in London: annual review (2018 data). London Public Health England; 2018.

4 Anderson SR, Maguire H, Carless J. Tuberculosis in London: a decade and a half of no decline [corrected]. Thorax 2007;62:162-7.

5 Anderson C, Story A, Brown T, et al. Tuberculosis in UK prisoners: a challenge for control. J Epidemiol Community Health 2010;64:373-6.

6 Story A, Murad S, Roberts W, et al. Tuberculosis in London: the importance of homelessness, problem drug use and prison. Thorax 2007;62:667-71.

7 GOV.UK. Health matters: reducing the burden of tuberculosis. Available: https://www.gov.uk/government/publications/healthmatters-reducing-the-burden-of-tuberculosis/health-mattersreducing-the-burden-of-tuberculosis [Accessed 13 May 2019].

8 Storla DG, Yimer S, Bjune GA. A systematic review of delay in the diagnosis and treatment of tuberculosis. BMC Public Health 2008;8:15.

9 World Health Organization. Early detection of tuberculosis: an overview of approaches, guidelines and tools. Geneva World Health Organization; 2011.

10 Bogale S, Diro E, Shiferaw AM, et al. Factors associated with the length of delay with tuberculosis diagnosis and treatment among adult tuberculosis patients attending at public health facilities in Gondar town, northwest, Ethiopia. BMC Infect Dis 2017;17:145.

11 Getnet F, Demissie M, Assefa N, et al. Delay in diagnosis of pulmonary tuberculosis in low-and middle-income settings: systematic review and meta-analysis. BMC Pulm Med 2017;17:202.

12 Quattrocchi A, Barchitta M, Nobile CGA, et al. Determinants of patient and health system delay among Italian and foreign-born patients with pulmonary tuberculosis: a multicentre cross-sectional study. BMJ Open 2018;8:e019673.

13 Pezzotti P, Pozzato S, Ferroni E, et al. Delay in diagnosis of pulmonary tuberculosis: a survey in the Lazio region, Italy. Epidemiol Biostat Public Health 2015;12:1-10.

14 Díez M, Bleda MJ, Alcaide J, et al. Determinants of health system delay among confirmed tuberculosis cases in Spain. Eur J Public Health 2005;15:343-9. 
15 Tattevin $\mathrm{P}$, Che D, Fraisse $\mathrm{P}$, et al. Factors associated with patient and health care system delay in the diagnosis of tuberculosis in France. int $j$ tuberc lung dis 2012;16:510-5.

16 Virenfeldt J, Rudolf F, Camara C, et al. Treatment delay affects clinical severity of tuberculosis: a longitudinal cohort study. BMJ Open 2014;4:e004818.

17 Asres A, Jerene D, Deressa W. Delays to treatment initiation is associated with tuberculosis treatment outcomes among patients on directly observed treatment short course in Southwest Ethiopia: a follow-up study. BMC Pulm Med 2018;18:64.

18 Saldana L, Abid M, McCarthy N, et al. Factors affecting delay in initiation of treatment of tuberculosis in the Thames Valley, UK. Public Health 2013;127:171-7.

19 Leutscher P, Madsen G, Erlandsen M, et al. Demographic and clinical characteristics in relation to patient and health system delays in a tuberculosis low-incidence country. Scand J Infect Dis 2012;44:29-36.

20 World Health Organization. Treatment of tuberculosis: guidelines for national programmes. 2nd Edition. Geneva, Switzerland: World Health Organization, 1997.

21 GOV.UK. Ethnic groups and how data on ethnicity is collected. Available: https://www.ethnicity-facts-figures.service.gov.uk/ ethnicity-in-the-uk/ethnic-groups-and-data-collected [Accessed 25 Mar 2019].

22 Hosmer D-W, Lemeshow S. Applied logistic regression. WileyInterscience, 1989.

23 Shannon K. TB delays in London: A study of socio-demographic risk factors for treatment delay.
24 Paynter S, Hayward A, Wilkinson P, et al. Patient and health service delays in initiating treatment for patients with pulmonary tuberculosis: retrospective cohort study. Int J Tuberc Lung Dis 2004;8:180-5.

25 Williams E, Cheng AC, Lane GP, et al. Delays in presentation and diagnosis of pulmonary tuberculosis: a retrospective study of a tertiary health service in Western Melbourne, 2011-2014. Intern Med J 2018;48:184-93.

26 Farah MG, Rygh JH, Steen TW, et al. Patient and health care system delays in the start of tuberculosis treatment in Norway. BMC Infect Dis 2006;6:33.

27 Rodger A, Jaffar S, Paynter S, et al. Delay in the diagnosis of pulmonary tuberculosis, London, 1998-2000: analysis of surveillance data. BMJ 2003;326:909-10.

28 Gissing S, Bindra R. Diagnostic delay in tuberculosis in Yorkshire \& Humber, UK: 2013-16 data. Eur Respir J 2018;52.

29 Yang W-T, Gounder CR, Akande T, et al. Barriers and delays in tuberculosis diagnosis and treatment services: does gender matter? Tuberc Res Treat 2014;2014:1-15.

30 Dedicoat MJ, Günther G, Crudu V, et al. Tuberculosis treatment outcomes in Europe: based on treatment completion, not cure. Am J Respir Crit Care Med 2017;196:1222-4.

31 Faustini A, Hall AJ, Perucci CA. Tuberculosis treatment outcomes in Europe: a systematic review. Eur Respir J 2005;26:503-10.

32 Lin Y, Enarson DA, Du J, et al. Risk factors for unfavourable treatment outcome among new smear-positive pulmonary tuberculosis cases in China. Public Health Action 2017;7:299-303.

33 NICE. Recommendations | tuberculosis | guidance. Available: https:// www.nice.org.uk/guidance/ng33/chapter/Recommendations\# adherence-treatment-completion-and-followup [Accessed 13 May 2019] 